\title{
Liturgy, Space, and Community in the Basilica Julii (Santa Maria in Trastevere)
}

\begin{abstract}
The Basilica Julii (also known as titulus Callisti and later as Santa Maria in Trastevere) provides a case study of the physical and social conditions in which early Christian liturgies 'rewired' their participants. This paper demonstrates that liturgical transformation was a two-way process, in which liturgy was the object as well as the agent of change. Three essential factors - the liturgy of the Eucharist, the space of the early Christian basilica, and the local Christian community - are described as they existed in Rome from the fourth through the ninth centuries. The essay then takes up the specific case of the Basilica Julii, showing how these three factors interacted in the concrete conditions of a particular titular church. The basilica's early Christian liturgical layout endured until the ninth century, when it was reconfigured by Pope Gregory IV (827-844) to bring the liturgical sub-spaces up-todate. In Pope Gregory's remodeling the original non-hierarchical layout was replaced by one in which celebrants were elevated above the congregation, women were segregated from men, and higher-ranking lay people were accorded places of honor distinct from those of lesser stature. These alterations brought the Basilica Julii in line with the requirements of the ninth-century papal stational liturgy. The stational liturgy was hierarchically organized from the beginning, but distinctions became sharper in the course of the early Middle Ages in accordance with the expansion of papal authority and changes in lay society. Increasing hierarchization may have enhanced the transformational power of the Eucharist, or impeded it.
\end{abstract}

The church known today as Santa Maria in Trastevere originated in the mid-fourth century as the "Basilica Julii". The fourth-century basilica was in use for eight hundred years, until it was demolished by Pope Innocent II (1130-1143) to make way for the building that stands today. Although many Roman churches share this millennial continuity of site and function, few have as rich a documentary and archaeological record as Santa Maria in Trastevere. This makes it a good case study of the dialogic interactions among liturgy, space, and community that characterize all sacred structures over time. My objective is to offer a few snapshots of the changing physical and social conditions in which early medieval Romans were - and were not - 'rewired'.

This essay stands in a long tradition of scholarship on architecture and liturgy in early Roman churches founded on the late nineteenth-century edition of the Liber pontificalis by 
the great Louis Duchesne. ${ }^{1}$ A modern milestone is Sible De Blaauw's path-breaking Cultus et decor of 1994, which reconstructs the setting and performance of the liturgy at various points throughout the middle ages in three papal basilicas: the Lateran Cathedral, St. Peter's, and Santa Maria Maggiore. ${ }^{2}$ Under De Blaauw's inspiration and leadership, the synthesis of architectural form and liturgical practice has become the focus of research on other early Christian and medieval Roman churches as well. ${ }^{3}$ My paper is also indebted to a trend in liturgical scholarship, represented by Joseph Dyer's publications on the schola cantorum and John Romano's book on "liturgy and society", that bridges the gap between liturgical scripts and the real world of their performers. ${ }^{4}$ Their work complements the brilliant studies of Peter Brown and his students on religious practices and beliefs in society outside the church. ${ }^{5}$ The aesthetic dimension of my analysis is in line with recent art historical emphasis on the affective properties of works of art and architecture, seen in such publications as Maria Fabricius Hansen's The Eloquence of Appropriation, which treats the effects of reused building elements (spolia) in early Christian churches, and Erik Thunø's studies of early medieval Roman apse mosaics and their inscriptions. ${ }^{6}$ Hansen's interpretative approach is influenced by the theory of "artistic will" (Kunstwollen) of Alois Riegl (d. 1905). ${ }^{7}$ She and Thun $\varnothing$ tend to accept the premise that affective artworks produced their intended results. My own stance is more skeptical, and my approach is to juxtapose factors calculated to produce liturgical transformation to other factors that might have been impediments.

\section{Liturgy}

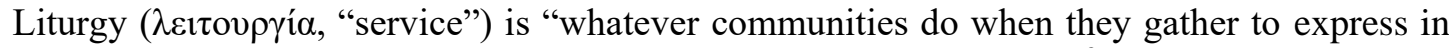
prayer, gesture, song, and symbol their identity as a religious group". ${ }^{8}$ Christians have multiple forms of liturgy. Among the most important when the Basilica Julii was founded were baptism, by which Jews and pagans were regenerated as "new men" and admitted to the community of the ecclesia; penance, by which Christians who committed mortal sins after baptism were absolved and restored to the community; and funerals, in which Christians passed from the community of the living to that of the dead. Individuals experienced these liturgies only once; they were non-repeatable. ${ }^{9}$ By contrast the liturgy of the Eucharist, in which Christians experienced membership in the ecclesia as one in the body of Christ, was available throughout their lives. ${ }^{10}$ This article focuses on the performance and perception of the Eucharist as it was celebrated in churches like the Basilica Julii before the twelfth century.

\footnotetext{
${ }^{1}$ Duchesne (ed.) 1886-92.

${ }^{2}$ De Blaauw 1994.

${ }^{3}$ De Blaauw 2000. This entire volume of MededRom is dedicated to "Cult furnishings and liturgical arrangements".

${ }^{4}$ Dyer 1993; Dyer 2008; Romano 2014.

${ }^{5}$ Brown 2012; Bowes 2008.

${ }^{6}$ Hansen 2003; Thunø 2011; Thunø 2015.

${ }^{7}$ For the critical fortune of Kunstwollen and a proposed modern alternative, see Elsner 2006.

${ }^{8}$ Taft 2000a, 44.

${ }^{9}$ The non-repeatable rite of penance was distinct from individual penance for venial sins, which was ongoing, and the annual collective rite established in the fifth century: White 1990.

${ }^{10} 1$ Cor. 10:17: Quoniam unus panis, unum corpus multi sumus, omnes qui de uno pane participamus.
} 


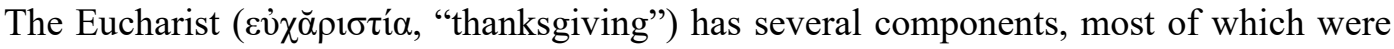
formalized by the second century: entrance, Scriptural readings, preaching, and prayers (the "Liturgy of the Word"); offerings and consecration of the gifts (the Eucharist proper); partaking of the consecrated gifts (communion); blessing and dismissal. ${ }^{11}$ Exactly how this skeleton was fleshed out in Rome is unknown before the seventh century. ${ }^{12}$ By that time the liturgy had two forms, one of the pope and the other of the intramural churches known as tituli. Tituli were district churches (quasi diocesis). ${ }^{13}$ Once considered the descendants of preConstantinian house churches, they are now thought to have been a Constantinian or postConstantinian innovation. ${ }^{14}$ Each titulus had its own resident priests (presbyteri) and lesser clergy.

The papal Mass, called a station (statio), was not always celebrated in the cathedral but moved from church to church according to the calendar of feasts and martyrs' commemorations. ${ }^{15}$ In 416, Pope Innocent I explained to the bishop of Gubbio that a piece of the bread consecrated in the papal Mass (the fermentum) was sent to the tituli so that priests who were attending to their own congregations would not "feel cut off from us in communion". ${ }^{16}$ The fermentum symbolized the unity of papal and presbyteral communions, but it may have done more. It could have been used to consecrate the elements in the tituli by contact, obviating the performance of the rite of consecration by the priests. ${ }^{17}$ Laypeople were permitted to take consecrated bread away with them in order to have communion at home during the week. ${ }^{18}$

In the seventh century the papal liturgy was renowned for its psalmody and its trained choir, the schola cantorum. ${ }^{19}$ Stations had proliferated, and nearly all of the 25 tituli hosted at least one statio per year. Detailed instructions (ordines) for the master of ceremonies enabled the performance of stational Masses in almost any setting. ${ }^{20}$ Several scholars have reconstructed this ideal statio on the basis of the earliest surviving ordo, Ordo Romanus I, which delineates the Easter Mass at Santa Maria Maggiore. ${ }^{21}$ Presbyters now celebrated the Eucharist in their tituli and the practice of sending the fermentum fell out of use. ${ }^{22}$ The titular liturgy had its own traditions, which sometimes differed from the papal one, and its performance was perforce much simpler, with fewer celebrants, fewer singers, and many fewer people. ${ }^{23}$ It would have been more personal, as it involved clerics and laypeople who lived in the same

\footnotetext{
${ }^{11}$ Baldovin 1991, 160-162.

${ }^{12}$ Vogel 1986, 37; Bradshaw 2014.

${ }^{13}$ Duchesne (ed.) 1886-92, vol. 1, 164, from the life of Pope Marcellus (308-309): XXV titulos in urbe Roma constituit, quasi diocesis, propter baptismum et paenitentiam multorum qui convertebantur ex paganis et propter sepulturas martyrum.

${ }^{14}$ Guidobaldi 1989; Guidobaldi 2000; Guidobaldi 2001-2002; Hillner 2007; Bowes 2008, 65-71; Brown 2012, 245-248; Spera 2013.

${ }^{15}$ Baldovin 1987, 143-147, with the caveat that his dating of the tituli is too early.

${ }^{16}$ Cabié (ed.) 1973, 26: De fermento vero quod die dominica per titulos mittimus ... Quarum presbiteri, quia die ipsa propter plebem sibi creditam nobiscum convenire non possunt, idcirco fermentum a nobis confectum per acolitos accipiunt, ut se a nostra communione maxime illa die non iudicent separatos; trans. Ellard 1948, 9.

${ }^{17}$ Taft 2000a, 413-416; Baldovin 2005; Bradshaw 2014, 13-14.

${ }^{18}$ Callam 1984, 615-626; Taft 2000a, 408-409; Bowes 2008, 54-58, 76-78; Bradshaw and Johnson 2012, 66-67.

${ }^{19}$ Dyer 2001; Dyer 2008. My thanks to Luisa Nardini for bibliographic advice.

${ }^{20}$ Vogel 1986, 135-147.

${ }^{21}$ Mathews 1962; Romano 2014, 29-51, 261-275.

${ }^{22}$ Taft 2000a, 416; Baldovin 2005, 41. The fermentum was still sent at Easter.

${ }^{23}$ Bradshaw 2014, 17; Brandt 2014, 50-51.
} 
neighborhood and met together on many occasions outside the Eucharist. Prayers for presbyteral Masses survive in the so-called Gelasian Sacramentary of the mid-eighth century, but there is no corresponding ordo. ${ }^{24}$ Most likely there was no common ordo for the tituli, as the churches differed in form and layout and celebrants must have adapted their performance accordingly.

\section{Space}

'Space' can be cultural, political, economic, topographical, cosmic, or something else, depending on the analyst's point of view. ${ }^{25}$ My subject here is architectural space, the "immaterial essence that ... the architect envelops, creating a wholly human and finite environment". ${ }^{26}$ Architectural space is made sensible by the absence of mass. ${ }^{27}$ Solid forms within the architectural envelope form sub-spaces, which may obscure the experience of the whole like the horizontal divisions of a skyscraper - or not. Most medieval churches enclose unbroken vertical volumes subdivided at floor level by barriers that regulate horizontal movement without denying the experience of the full height and breadth of the whole. The sub-spaces direct traffic and express hierarchical distinctions among those who are permitted to enter them and those who are not.

The modern paradigm of medieval church space is the Gothic cathedral. Emphatically vertical, capped by soaring vaults floating above the glow of colored windows and enclosed by walls adorned with figural sculpture, Gothic space is both ineffable and informational. A recent study of Chartres Cathedral calls it a form of rhetoric, designed to stimulate spiritual reflection within those who traverse it. ${ }^{28}$ The space of the early Christian basilica has received less attention, but it too was affective and rhetorical. The Constantinian basilicas of Rome the Lateran Cathedral and St. Peter's - were towering structures that enveloped enormous spaces. $^{29}$ (St. Peter's nave was taller than the high vaults of Chartres and one-and-one-half times wider. ${ }^{30}$ ) The elevations defied architectonic expectations by placing solid walls over the voids and slender masses of colonnades, making them seem other-worldly. ${ }^{31}$ The ethereal impression was intensified by scintillating surface ornament - highly polished marbles, gold mosaic, gilded roof beams or ceilings - illuminated by exceptionally large windows in the nave walls and numerous gold and silver hanging lamps and candelabra at ground level. ${ }^{32}$ The effect has been compared to epideictic rhetoric and specifically to panegyric, or speeches of praise. ${ }^{33}$ The panegyrical spaces of Constantinian basilicas praised both God and his imperial devotee. Inscriptions and figural imagery in the apse and - in the fifth century - on the

\footnotetext{
${ }^{24}$ Mohlberg (ed.) 1960; Vogel 1986, 64-70; Chavasse (tr.) 1997. The Gelasian Sacramentary is a composite, and not all of its Masses are titular: Coebergh 1961.

${ }^{25}$ Palazzo 2008, 13-23; Cassidy-Welch 2010, 1-8.

${ }^{26}$ Ackerman n.d.

${ }^{27}$ Ackerman n.d.

${ }^{28}$ Crossley 2010.

${ }^{29}$ Brandenburg 2004, 20-37, 91-102.

${ }^{30}$ Bozzoni 1997, 64.

${ }^{31}$ De Blaauw 2010, 50.

${ }^{32}$ Davis (tr.) 1989, 115; Barry 2013.

${ }^{33}$ Wohl 2001, 98-106; Hansen 2003, 225-236.
} 
nave walls marked the spatial frame as distinctively Christian. Titular basilicas, though small and modest by comparison, strove for similar spatial and ornamental effects. ${ }^{34}$

The Eucharistic liturgy had to change, physically and dramatically, to fill the space of the Constantinian basilica. Pre-baptismal instruction increasingly stressed the Eucharist's fearsome power. ${ }^{35}$ The liturgy became longer and grander; prayers and psalmody expanded, while readings decreased. Celebrants followed a more majestic choreography. The designers of the Lateran Cathedral provided sub-spaces that directed their movement and limited their contact with the congregation (FIG. 1). ${ }^{36}$ In the nave, archaeologists have found the footings of two marble balustrades lining the longitudinal axis, which divided the space into left and right halves with a pathway (solea) about $2.5 \mathrm{~m}$ wide between them. ${ }^{37}$ The solea ended at another subdivision, the fastigium ("apex" or "pediment"), which seems to have been a tall transverse colonnade comprising four bronze columns and a superstructure with silver statues facing "front" toward the nave and "behind" toward the apse. ${ }^{38}$ The Eucharist altar stood behind the fastigium. Sible De Blaauw placed it about $10 \mathrm{~m}$ forward from the apse, on the assumption that the apse itself was occupied by the bishop's throne (cathedra) and other seating for the clergy. ${ }^{39}$ Constantine donated seven more altars of silver, presumably for the offertory rite, which De Blaauw suggested were installed at the ends of the inner aisles. ${ }^{40}$

The sub-spaces strictly segregated men from women (in the south and north sides of the nave respectively) and both from the pope and higher clergy. The planners must have envisioned a monumental entrance procession through the nave and an offertory in which men and women separately brought their gifts to the designated altars. Further evidence of the anticipated performance is given by the list of Eucharistic vessels in the Liber pontificalis, which included 23 gold and silver patens, 27 gold and silver cups (scyphi), 2 large (26-liter) gold pitchers (amae) and 20 smaller ones of silver, 90 gold and silver chalices, and one extraordinary scyphus of coral, covered with jewels and gold, that weighed more than 20 pounds. ${ }^{41}$ Even if the quantities are bloated by post-Constantinian additions, as some have argued, the large sizes and capacities of these vessels indicate very large numbers of participants in the offertory and communion. ${ }^{42}$ Offerings of wine would have been poured into the

\footnotetext{
${ }^{34}$ Kinney 2010, 59-63.

${ }^{35}$ Baldovin 1991, 168-169; Bradshaw and Johnson 2012, 64.

${ }^{36}$ De Blaauw 1994, vol. 1, 140-147.

${ }^{37}$ De Blauuw 1994, vol. 1, 127-129; doubted by Guidobaldi 2001, 185-187.

${ }^{38}$ Duchesne (ed.) 1886-92, vol. 1, 172, from the life of Pope Sylvester (314-335): [Constantinus augustus posuit] fastidium [sic] argenteum battutilem, qui habet in fronte Salvatorem sedentem in sella ... item a tergo respiciens in absida, Salvatorem sedentem in throno... On the vexed question of the fastigium see De Blaauw 1996; Geertman 2001-2002; Caseau 2012, 540-543; Brandt 2016. I'm grateful to Paolo Liverani for discussion of the latest research.

${ }^{39}$ De Blaauw 1994, vol. 1, 117-119.

${ }^{40}$ Duchesne (ed.) 1886-92, vol. 1, 172: altaria VII ex argento purissimo, pens. sing. lib. CC; Guidobaldi 2001, 173.

${ }^{41}$ Duchesne (ed.) 1886-92, vol. 1, 172-173: patenas aureas VII, pens. sing. lib. XXX; patenas argenteas XVI, pens. sing. lib. XXX; scyphos auro purissimo VII, pens. sing. lib. X; scyphum singularem ex metallo coralli, ornatum ex undique gemmis prasinis et yaquintis, auro interclusum, qui pens. ex omni parte lib. XX et uncias III; scyphos argenteos XX, pens. sing. lib. XV; amas ex auro purissimo II, pens. sing. lib. L, portantes singulae medemnos III; amas argenteas XX, pens. sing. lib. X, portantes singulae medemnos singulos; calices minores aureos purissimos XL, pens. sing. lib. singulas; calices minores ministeriales $L$, pens. sing. lib. II.

${ }^{42}$ Caseau 2012, 537-548.
} 
large amae, and some of the bread laid on the gold patens. ${ }^{43}$ Wine needed for the Mass would have been transferred from the amae to scyphi on the altars, and from them to a large chalice for consecration. The small ("ministering") chalices were for communion. If De Blaauw is right that gold plate was for the clergy and silver for the populus, the vessels provided for a great many clergy (40 chalices) and even more people (50 chalices). ${ }^{44}$ The abundance of silver chalices supports the idea that communion was meant to be administered along the solea, in order to serve as many people as possible at the same time. ${ }^{45}$

Making the Eucharist more auratic seems to have had the perverse effect of diminishing lay participation in communion. ${ }^{46}$ Intimidated by perceptions of unworthiness, people attended Mass but abstained from taking the sanctified bread and wine, allowing priests to do it on their behalf. "The Eucharist ... not only ceased to be a communal action but was no longer even viewed as food to be eaten. Instead, it became principally an object of devotion, to be gazed on from afar". ${ }^{47}$ Although this development is not documented for Rome specifically, there is no reason to think it did not occur there. The hierarchical distinctions imposed by the Lateran sub-spaces reinforced the status-consciousness of the groups assigned to them, especially the laity.

The Lateran sub-spaces made no specific provision for the Liturgy of the Word. Unlike many bishops elsewhere, the pope normally did not give a sermon. ${ }^{48} \mathrm{Had}$ he preached from the cathedra, no one but the surrounding clergy could have heard him. Readings and chants performed anywhere near the fastigium would likewise have been inaudible to all but a few in the nave. A portable lectern set up in the solea would not have dispelled the impression that the cathedral was designed primarily for the Eucharist proper: offerings, consecration, and communion. Even this performance would have been invisible to the most of the populus, whose spaces were too far away.

The tituli, by contrast, were places of teaching. Title-priests were responsible for making converts to Christianity and for preparing candidates for baptism. ${ }^{49}$ Their congregations included many - pagans, catechumens, penitents - who would have been excluded from communion but not from the Liturgy of the Word. Nevertheless, in plan and layout the tituli were often small versions of the cathedral, with a nave, two aisles, and an apse on the short wall facing the entrance. ${ }^{50}$ Traces of transverse and longitudinal subdivisions have been found in several of them, including the titulus Marci (founded by Pope Mark, 336) and the titulus Clementis (late fourth century?). In these cases the enclosures were later insertions, but in the titulus Damasi (San Lorenzo in Damaso, 366-384) excavators discovered what may have been a solea in the original pavement. ${ }^{51}$ Fixed liturgical sub-spaces seem to have been stand-

\footnotetext{
${ }^{43}$ For this and what follows: Geertman 1987; Davis (tr.) 1989, 107-108; De Blaauw 1994, vol. 1, 142-146; Caseau 2007, 554-558.

${ }^{44}$ De Blaauw 1994, vol. 1, 143.

${ }^{45}$ Saxer 2000, 72-73; Brandt 2014, 51.

${ }^{46}$ Bradshaw and Johnson 2012, 66.

${ }^{47}$ Bradshaw and Johnson 2012, 67.

${ }^{48}$ Mathews 1962, 86; Romano 2014, 50-51.

${ }^{49}$ Cosentino 2002, 142.

${ }^{50}$ Brandenburg 2004, 110-113, 134-176, 189-198; Kinney 2010, 59-63, 69-71.

${ }^{51}$ San Marco: Cecchelli 1995, 643; San Lorenzo in Damaso: Krautheimer and Pentiricci 2009, 275-276.
} 
ard in tituli by the sixth century. ${ }^{52}$ Where they existed, the choreography of the presbyteral Eucharist must have been essentially the same as that in the cathedral.

\section{Community}

The ecclesia is a mystic community united in the body of Christ. ${ }^{53}$ Its purpose-built basilicas - metonymically also called ecclesiae - were perceived from the outset as metaphors of the community and vice versa. Preachers were inspired by the many architectural similes in Scripture, such as St. Paul's well-known invocation of the cornerstone (Ephesians 2:19-22), and their sermons on the dedication of churches called up these similes in the presence of the real columns, windows, ceilings, walls, and doors of the building in which the congregation was standing. Listeners were encouraged to think of these elements as symbols of a spiritual edifice of which they themselves were a part. ${ }^{54}$

The spiritual Church transcends time and space to include all members in Christ living and dead. Individuals join this ideal community through the Eucharist, and it is through the Eucharist that they experience it. In liturgical communion they escape the limitations of the Church in the world. The fourth-century Church was actually a network of individual churches, based in cities and headed by bishops. ${ }^{55}$ Each bishop's church was a community, with its own dead, its own liturgical traditions, and its own imagined unity. The unity of the church of Rome was symbolized by the enormous space of the Lateran Cathedral, the stational Mass, the fermentum, and the tituli. In practice, however, it was socially stratified and periodically riven by political and doctrinal oppositions. Only a few years after it was founded, the Basilica Julii was occupied by a rival of Pope Liberius (352-366) who "dared to give a station" there, signaling his own claim to be pope. ${ }^{56}$ Not long afterward a fight between supporters of Liberius's would-be successors killed 137 people in a single day, and "it was only with difficulty that the ... frenzy of the people was afterwards quieted". ${ }^{57}$ Schismatic elections and their violent aftermaths continued to divide the Roman church throughout the middle ages.

Church communities exist within larger societies structured by categorical distinctions: rich and poor, aristocratic and common, male and female. ${ }^{58}$ The ideal Christian community eliminates such distinctions, but it has its own hierarchy in the priesthood. In the mid-fourth century bishops and priests were often "subelites", men from the mediocres or "moderately well-to-do" classes, to which their congregations also belonged. ${ }^{59}$ Socially, they ranked below post-Constantinian converts from the senatorial class. ${ }^{60}$ Scholars differ about the extent to which the privileges of the higher classes carried over into the church. Peter Brown opined that class and cultural boundaries broke down, or were at least "suspended", as aristocrats

\footnotetext{
${ }^{52}$ Guidobaldi 2001, 187-190; Brandt 2014, 45-52.

${ }^{53}$ John Paul II 2003. The doctrine is unchanged since the time of St. Paul (1 Cor. 12-26).

${ }^{54}$ Sotinel 1997; Repsher 1998, 27-33; Hansen 2003, 197-204, 212-219.

${ }^{55}$ Louth 1996, 10-15.

${ }^{56}$ Guenther (ed.) 1895, 2: inrumpit in urbem et stationem in Iuli trans Tiberim dare praesumit; Baldovin 1987, 144; De Spirito 1999, 84.

${ }^{57}$ Rolfe (tr.) 1971-1972, vol. 3, 19-21: uno die centum triginta septem reperta cadavera peremptorum, efferatamque diu plebem aegre postea delenitam; Humphries 2014, 181-182.

${ }^{58}$ Humphries 2014.

${ }^{59}$ Brown 2012, 36-39.

${ }^{60}$ Sessa 2012, 28-29.
} 
sought to join with mediocres in an idealized Christian social order, while Mark Humphries argued that "the grubby reality of social life" was inescapable, and "the liturgy occurred amidst a context in which traditional displays of secular status continued to be made". ${ }^{61}$ Ramsay MacMullen even posited two different Christianities, one of the top 5 percent of Romans and another of the remaining 95 percent, "lowly bureaucrats, petty retailers, peddlers, artisans, laborers, rustics". According to MacMullen the 95 percent tended to perpetuate ancestral customs and rituals, frequented extramural cemetery churches and the shrines of martyrs, and generally "worshipped in their own way". ${ }^{62}$ The 5 percent attended intramural churches, absorbed the doctrines inculcated by the clergy and the liturgy, and constituted an 'establishment'.

Gender distinctions were stark. Roman women were socially and legally subordinate to men. ${ }^{63}$ Christian writers of the third and fourth centuries rationalized this subordination on theological grounds or reinforced it with moral stereotypes, casting women as weak, sensual, and susceptible to vice. ${ }^{64}$ At least one churchman questioned whether menstruation was grounds for denying women baptism and the Eucharist; Pope Gregory I (590-604) replied no, but not without remarking that menstruous women who reverently abstained from the Sacrament merited praise. ${ }^{65}$ John Chrysostom (d. 407) blamed women for distracting men in church with their dress and make-up, and advocated a wall to keep the sexes apart. ${ }^{66}$ Women were excluded from public teaching and the priesthood, and while Eastern churches ordained women as deacons, the office of deaconess did not exist in Rome. ${ }^{67}$ The only roles for women in the Roman church were those of consecrated virgins (sanctimoniales) and widows (vidu$a e$ ): women over the age of 40 and 60 respectively, who vowed to abstain from (re)marriage and sexual relations. They had special seating in church but were forbidden to speak. ${ }^{68}$ Wealth and social stature allowed elite women to participate on their own terms, however. Many maintained churches in their homes, with their own priests and visiting teachers. ${ }^{69}$ Some became influential benefactors, supporting the work of scholars like St. Jerome and funding churches and monasteries in their own names, like the titulus Vestinae. ${ }^{70}$

Social rank was recognized in the stational liturgy, at least by the time of its codification in the seventh century. The Ordo Romanus I describes the pope descending to a senatorium during the Offertory to personally receive the gifts of the noblemen in order of precedence, and then passing to the women's side (pars feminarum) to do the same. The bishop of the

\footnotetext{
${ }^{61}$ Brown 2012, 31-52; Humphries 2014, 172, 179.

${ }^{62}$ MacMullen 2009, 15, 104-111. The 95 percent does not explicitly include slaves, who by the author's estimate (p. 70) constituted nearly one-third of Rome's population in the third century.

${ }^{63}$ Grubbs 1993, 136-137; Wijngaards 2001, 51-54; Salzman 2002, 138-177.

${ }^{64}$ Clark 1994, 166-178; Lunn-Rockliffe 2007, 89-99.

${ }^{65}$ Colgrave and Mynors (eds.) 1969, 92: Si autem ex ueneratione magna percipere non praesumit, laudanda est. Wood 1981, 713-714, 726; Branham 2002, 19-20; Muschiol 2004, 206-207.

${ }^{66}$ Taft 2000b, 14, citing Homilies on Matthew 73/74.3 (PG 58, 677).

${ }^{67}$ Gryson 1976, 71-72; Wijngaards 2001, 139-145.

${ }^{68}$ Gryson 1976, 102-105; Salzman 2002, 171-173; Brown 2012, 282-285.

${ }^{69}$ Bowes 2008, 61-63, 75-103; Sessa 2012, 56-57.

${ }^{70}$ Clark 1990, 259-264; Salzman 2002, 173-175; Brown 2012, 273-282. Titulus Vestinae: Duchesne (ed.) 1886-92, vol. 1, 220-222: ex devotione cuiusdam inlustris feminae Vestinae; Hillner 2007, 231; Bowes 2008, 92-93.
} 
week takes the gifts of the remaining men. ${ }^{71}$ Later the pope again descends from the cathedra to give the communion bread to the occupants of the senatorium, after which he moves to the left side (pars sinistra) to give it to the women. ${ }^{72}$ Bishops and deacons communicated the remaining men and priests communicated the women. In the Byzantinized ceremony of the early medieval Ordo, senatorium is an archaism from the status system of late antiquity. ${ }^{73}$ This does not mean that the choreography of $O R I$ goes back to the fourth century, but some accommodation for senatores and matronae must have existed then as well. Even if a senator had "many slaves surrounding him to shoo away the crowd", it would have been an offense to make him wait among the masses in the nave of the cathedral to present his gifts or to receive the consecrated bread and wine. ${ }^{74}$

\section{Basilica Julii / Titulus Callisti / Santa Maria in Trastevere}

The Basilica Julii was constructed by Pope Julius I (337-352) in the section of Trastevere that had been enclosed within the defensive wall of Aurelian some 75 years before. The zone had become more densely populated after the construction of the wall, even as it lost its source of good water from the Aqua Virgo. ${ }^{75}$ Trastevere lacked public amenities like the thermae, which were built for the upper classes; most of its residents were at best mediocres: artisans, laborers, and shopkeepers, including many transients. ${ }^{76}$ The population was mixed, with a high percentage of foreigners. It was known for its artisans. The region had no temples to the state gods; instead there were numerous cult sites of Syrian and other foreign deities and a significant number of Jews. ${ }^{77}$ The demographic augured well for conversions to Christianity and probably included many who were already Christian. Pope Julius's basilica stood "iuxta Callistum", conceivably the site of the school of the third-century pope Callixtus I (217-222), which is said to have attracted throngs of people. ${ }^{78}$ Although the remains of a domestic structure found under the present basilica are too late to have housed this school, probably one or more pre-Constantinian meeting places stood nearby. ${ }^{79}$

The Basilica Julii lies directly under the extant church of Santa Maria in Trastevere. Its apse was uncovered under the nave pavement in 1865 and again in $1994 .^{80} \mathrm{~A}$ second apse, added in the middle ages, was aligned with the left (south) aisle, indicating an aisled basilica with colonnades on the lines of the present ones (FIG. 2) ${ }^{81}$ If the entrance wall of this basilica was also under the present one, it would have been $37 \mathrm{~m}$. long (42 m. including the apse) and

\footnotetext{
${ }^{71}$ Mathews 1962, 88-89; De Benedictis 1981, 69-70; Romano 2014, 240-241: Pontifex autem descendit ad senatorium ... et suscipit oblationes principum per ordinem archium ... Similiter ascendens [from the confession] ... a parte feminarum ordine quo supra omnia explet.

${ }^{72}$ Mathews 1962, 89-90, 94 Fig. 1; Romano 2014, 246-247, also 34-35, 97-99, 227.

${ }^{73}$ Llewellyn 1970, 125-126; Barnish 1988, 149-155; Romano 2014, 97-99.

${ }^{74}$ Humphries 2014, 179, citing John Chrysostom, Homilies on 2 Thessalonians, 3.3 (PG 62, 484).

${ }^{75}$ Dey 2011, 172-173, 183.

${ }^{76}$ Purcell 1999, 138-139.

${ }^{77}$ Maischberger 1999, 80-83.

${ }^{78}$ Mommsen (ed.) 1892, 76: [Iulius fecit] basilicam trans Tiberim regione XIIII iuxta Callistum. Marcovich (ed.) 1986,

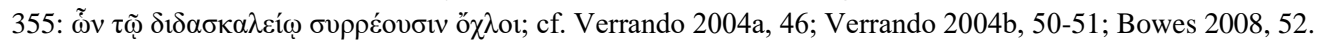

${ }^{79}$ Coccia et al. 2012, 41-45, 51-52.

${ }^{80}$ Kinney 1975; Coccia et al. 2000; Coccia et al. 2012.

${ }^{81}$ Coccia et al. 2012, 52-53.
} 
$25 \mathrm{~m}$. wide. Using MacMullen's module of one square meter per person, the nave would have held about 450 people standing shoulder to shoulder. ${ }^{82}$ Allowing space for the clergy and the altar, the maximum number of laypeople might have been more like 300 .

The basilica was likely founded as a titulus, although it is not recorded as such until the fifth century. ${ }^{83}$ Pope Celestine I (422-432) replaced its silver communion vessels after the "Gothic fire" of 410: a 25-pound paten, two 8-pound scyphi, two 10-pound amae, five 3pound chalices, and hand-washing basins, as well as various hanging and standing lamps. ${ }^{84}$ The quantities and weights are tiny compared with those of the cathedral, but they are very similar to Pope Sylvester's donation of plate to the titulus Equitii as recorded in the Liber Pontificalis. ${ }^{85}$ According to a ninth-century source, the altar on which these vessels would have been used was "in a low place, almost in the middle of the nave". It seems to have been accessible to the populus, as "people of both sexes gathering round it [were] intermingled in a disorderly way with the clergy" during Mass. ${ }^{86}$ Although not otherwise attested in Rome, this position of the altar was common in North Africa in the fourth and fifth centuries. ${ }^{87}$ It is visualized in the well-known mosaic of "Ecclesia Mater" in the Bardo Museum (Tunis), which was commissioned to cover the tomb of a lady named Valentia in Tabarka (FIG. 3). ${ }^{88}$ The mosaic shows a church with its apse raised five steps above the nave and the altar standing on the nave pavement below. The position of the celebrant "in the midst of the clergy and the faithful" was common in North Africa. ${ }^{89}$ The raised apse may have been used for preaching.

Preaching and teaching may likewise have occurred in the apse of the Basilica Julii. As a titulus it was an outpost of the papacy in Trastevere. Its priests must have been charged not only to prepare catechumens for baptism, but to proselytize among their non-Christian neighbors and to woo the proprietors of private house-churches - like that of the clarissima in which Ambrose of Milan not only celebrated the Eucharist but also healed a man suffering from paralysis - away from their unofficial establishments. ${ }^{90}$ Teaching is thematized in the late fourth-century apse mosaic of the titulus Pudentis (Santa Pudenziana), which shows Christ among his "co-philosophers", the Apostles (FIG. 4). The mosaic itself was a vehicle of teaching. ${ }^{91}$ If, as Thomas Mathews argued, Christ was a double of the teaching pope, the cophilosophers would represent the presbyters who spread Christ's teaching among the peo-

\footnotetext{
${ }^{82}$ MacMullen 2009, 12. The nave is $12.5 \mathrm{~m}$. wide between the colonnades.

${ }^{83}$ Mommsen (ed.) 1894, 411: Paulinus presbyter tituli Iuli subscripsi.

${ }^{84}$ Duchesne (ed.) 1886-92, vol. 1, 230: Hic dedicavit basilicam Iuli in qua optulit post ignem Geticum patenam argenteam, pens. lib. XXV; scyphos argenteos II, pens. sing. lib. VIII; amas argenteas II, pens. sing. lib. X; calices minores argenteos V, pens. sing. lib. III; aquamanules argenteos, pens. lib. X; candelabra argentea II, pens. sing. lib. XXX; canthara cereostata aerea XXIIII, pens. sing. lib. XXX; item coronas argenteas $X$, pens. sing. lib. X. Not everyone agrees that the basilica Iuli in question was the one in Trastevere; see De Spirito 1993.

${ }^{85}$ Duchesne (ed.) 1886-92, vol. 1, 170; Caseau 2007, 554-555.

${ }^{86}$ Duchesne (ed.), 1886-92, vol. 2, 80, from the life of Pope Gregory IV (827-844): altare in humili loco situm fuerat, pene in media testudine, circa quod plebs utriusque sexus conveniens, pontifex cum clero plebi confuse inmixto sacra misteria celebrabat.

${ }^{87}$ Duval 2005, 14; Jensen 2015, 104-108. The parallel is doubted by De Blaauw 2001, 976-977.

${ }^{88}$ Gauckler 1906, 188-197; Ward-Perkins and Goodchild 1953, 57-58.

${ }^{89}$ Duval 2005, 15; Jensen 2015, 104-113.

${ }^{90}$ Bowes 2008, 80-82 (Trastevere); Bradshaw 2014, 11-13, 18. I differ from Bowes 2008, 102-103, who describes the tituli as similar to house-churches rather than aligned with the pope.

${ }^{91}$ Mathews 1993, 109-111; Andaloro 2006.
} 
ple. ${ }^{92}$ Titular presbyters were not all as learned as the so-called Ambrosiaster, a late fourthcentury Roman priest whose sermons have been partially preserved, but like him they must have been "in constant dialogue with lay questioners". 93

When, by the late fifth or sixth century, the population of Rome was fully Christianized, the teaching function of the tituli was focused on catechumens, whose preparation for baptism was concentrated in the 40 days of Lent. Lenten stations were established in 22 tituli, bringing the pope to all regions of the city in a symbolic display of the oneness of the Roman church and its Lenten instruction. ${ }^{94}$ Only three tituli were omitted from this rotation: Silvestri (the former titulus Equitii), Praxedis, and Callisti (= Iulii, Santa Maria in Trastevere). ${ }^{95}$ Antoine Chavasse opined that these three were overlooked because their neighborhoods were served by stations at other tituli nearby. ${ }^{96}$ Be that as it may, the titulus Iulii et Callisti did not regularly host a papal Mass until the early eighth century, when Pope Gregory II (715-731) created new stations for Lenten Thursdays. ${ }^{97}$ In the meantime the original disposition of the altar, suited to the conditions of the fourth century, remained unchanged. Its accessible location was appropriate for a small congregation with relatively few social stratifications. If the women who mingled with the men during the Eucharist enjoyed a special status, they could have been sanctimoniales and viduae or the wives of the presbyters (who, paradoxically, also were virgins). ${ }^{98}$ The introduction of an annual papal Mass exposed the inadequacy of this arrangement to the social order of the eighth century. By the ninth century it was intolerable, and Pope Gregory IV (827-844) sponsored a massive renovation to bring the titulus up-todate.

Women were not even the greatest problem. Relics of the namesake of the titulus, Pope Callixtus I, and two other saints had been buried without sufficient honor in the south aisle; at the same time, there is no notice of relics in the nave. ${ }^{99}$ If the altar in the nave did not contain relics, it was in violation of the decree of the Seventh Ecumenical Council at Nicaea (787) that all altars should have them. ${ }^{100}$ Gregory IV remedied the situation by moving the saints' bodies from the south aisle to a "secret cavity" in the western apse, around which he piled up fill to make a podium (tribunal) enclosed by stone parapets. He set the altar on the tribunal and made a window (confessio) below it to provide a connection to the relics. In front of the tribunal he made a presbyterium with a matroneum on its northern side, enclosed by a balustrade. ${ }^{101}$ As reconstructed by Karin Einaudi (FIG. 5), Gregory IV's renovation resembles the late sixth-century remodeling of St. Peter's basilica, in which the apse floor was raised to cover the Apostle's tomb and the altar set directly above it, so that Mass could be celebrated

\footnotetext{
${ }^{92}$ Mathews 1993, 113-114.

${ }^{93}$ Lunn-Rockliffe 2007, esp. 63-86; Hunter 2009; quotation from Brown 2012, 255. Lunn-Rockliffe (84) suggests that he was a presbyter at a cemetery basilica, but cemeteries were in the charge of tituli (above, n. 13).

${ }^{94}$ Chavasse 1982.

${ }^{95}$ Callisti was added to the title of the church in the sixth century.

${ }^{96}$ Chavasse 1982, 31.

${ }^{97}$ Kirsch 1926, 134-135.

${ }^{98}$ Sessa 2012, 174-192.

${ }^{99}$ Duchesne (ed.) 1886-92, vol. 2, 80, quoted by Bauer 2000, 124 n. 2, and Einaudi 2000, 176-177. See Bauer 2000, 104 Fig. 3.

100 Jensen 2014, 161.

${ }^{101}$ Duchesne (ed.) 1886-92, vol. 2, 80, quoted by Bauer 2000, 124 n. 2, and Einaudi 2000, 176.
} 
over the body. ${ }^{102}$ Several other tituli were given similar papalizing (or "Petrine") overhauls in the ninth century. ${ }^{103}$ Like the stational rotation in Lent, the new staging of the altar symbolized the unity of the church of Rome under the pope. The new liturgical sub-spaces accommodated the stational liturgy and conversely, the sub-spaces forced the regular liturgy of the tituli into the papal mold. ${ }^{104}$ All celebrations of the Eucharist now entailed the elevation of the celebrants above the populus, fixed places at nave level for lesser clergy and singers, and physical barriers separating them from the laity.

The stational liturgy of the $O R I$ actively promoted the hierarchical organization of the early medieval papal court. ${ }^{105}$ In the Offertory and Communion rites, it also acknowledged the hierarchy of lay society, whose upper ranks were no longer the senatorial aristocracy of late antiquity, but new men bearing the titles of military leaders and the former imperial (Byzantine) administration. ${ }^{106}$ The word senatus was revived, shorn of any political meaning, to denote the uppermost class. ${ }^{107}$ The septum matroneum built by Pope Gregory IV adjoining the presbyterium was most likely the counterpart of a senatorium, where the pope descended to personally minister to the lay nobility. ${ }^{108}$ Permanent enclosures would have marked social distinctions among the laity in non-stational Masses as well. There was a local aristocracy in Trastevere at least by the tenth century, albeit a relatively modest one. ${ }^{109}$

\section{Conclusion}

The history of the Basilica Julii coincided with a momentous transformation of the Christian community in Rome. From a small religious sect the community grew to absorb the entire population of the city. Its clergy moved into the ruling class, and Rome became a theocracy in which distinctions between priests and laypeople were ever more sharply drawn. Tituli were reconfigured from neighborhood centers of instruction and pastoral care to become theaters for the majestic papal liturgy. In the absence of historical testimonies, we can only conjecture how these changes affected the subjective experience of the Eucharist among its participants. This paper proposes that the experience was influenced, or even determined, by the participant's location in an architectural enclosure (higher or lower, visible or invisible, near or far from the altar, proximate or not to other people). Since such spatial determinants changed over time, the experience must have changed as well. Through the insertion of new subdivisions, the nave of the Basilica Julii ceased to be a single space allowing fluid movement around one or more tables, becoming instead something like a theater or a throne room, in which the celebration of the Eucharist became a spectacle and barriers kept performers and their audience strictly apart. Presumably, the segregation reinforced group identities - clergy and lay, noble and common, male and female - that existed and originated in the world outside the church. Awareness of such distinctions must have conditioned the liturgical experi-

\footnotetext{
${ }^{102}$ Einaudi 2000; Bauer 2000, 104 Fig. 4; for St. Peter's: De Blaauw 1994, vol. 2, 530-556.

${ }^{103}$ Bauer 2000, 101-114; Emerick 2000, 148-151.

${ }^{104}$ Bauer 2000, 117-121.

${ }^{105}$ Romano 2014, 75-107.

${ }^{106}$ Marazzi 2001, 41-62.

${ }^{107}$ Marazzi 2001, 58-60.

${ }^{108}$ On the difficult term matroneum see De Benedictis, 1981; Einaudi 2000, 193 n. 8. Bauer 2000, 104 Fig. 4 places it at the end of the north aisle.

${ }^{109}$ Wickham 2015, 128-129.
} 
ence, and was in constant tension with the ideal of one spirit in one body that is held to be the essence of Christian communion. ${ }^{110}$

The elevated, segregated, more visible position of the clergy in the ninth-century basilica (FIG. 5) reinforced the clergy's claim to moral superiority over laypeople and unique access to God. The position of the congregants at floor level, looking up at the Eucharistic celebration from outside a wall of stone parapets, emphasized their lesser status and their need to approach God through intermediaries. From a modern democratic perspective, this concretization of hierarchy may seem like an alienating obstacle to communion, but members of an innately hierarchical society might have taken it for granted. Similarly, the enhancement of the visual and auditory spectacle of the Mass by affective environmental factors (candles, incense, expansive space, apse mosaics, other forms of gleaming decoration) could have promoted transcendence of hierarchical distinctions, or it might have reaffirmed them by exalting the men who controlled the candles and the incense and the space. Rather than the pure communion described by theoreticians of the Eucharist, early medieval Romans may have been uplifted by the mere sight of those whom they believed to be familiars of God. Or not. The material evidence is ambiguous, but it is still a useful corrective to the written record, which almost by definition preserves the view from the top.

\section{Dale Kinney}

Bryn Mawr College

dkinney@brynmawr.edu

\footnotetext{
${ }^{110} 1$ Cor. 13: etenim in uno Spiritu omnes nos in unum corpus baptizati sumus, sive Iudaei sive Gentiles, sive servi sive liberi, et omnes in uno Spiritu potati sumus.
} 


\section{BIBLIOGRAPHY}

Ackerman J.S. n.d.: "Space and Mass", in Encyclopaedia Britannica, from https://www.britannica.com/topic/architecture/Space-and-mass (accessed 07-III2018).

Andaloro M. 2006: "Il mosaico absidale di Santa Pudenziana”, in M. Andaloro (ed.), L'orizzonte tardoantico e le nuove immagini 312-468. La pittura medievale a Roma, Corpus, vol. 1, Milan, 114-124.

Baldovin J.F. 1987: The Urban Character of Christian Worship. The Origins, Development, and Meaning of Stational Liturgy, Rome.

Baldovin J.F. 1991: "Christian Worship to the Eve of the Reformation", in P. F. Bradshaw, L.A. Hoffman (eds.), The Making of Jewish and Christian Worship, Notre Dame IN, 156-183.

Baldovin J.F. 2005: "The Fermentum at Rome in the Fifth Century: A Reconsideration", Worship 79, 3853.

Barnish S.J.B. 1988: "Transformation and Survival in the Western Senatorial Aristocracy, c. A.D. 400700", BSR 56, 120-155.

Barry F. 2013: "The House of the Rising Sun: Luminosity and Sacrality from Domus to Ecclesia", in A. Lidov (ed.), Hierotopy of Light and Fire in the Culture of the Byzantine World, Moscow, 82-104.

Bauer F.A. 2000: "The Liturgical Arrangement of Early Medieval Roman Church Buildings", MededRom 59, 101-128.

Bowes K. 2008: Private Worship, Public Values, and Religious Change in Late Antiquity, Cambridge.

Bozzoni C. 1997: “L'immagine dell'antico San Pietro nelle rappresentazioni figurate e nella architettura costruita", in G. Spagnesi (ed.), L'architettura della Basilica di San Pietro, Storia e costruzione. Atti del Convegno Internazionale di Studi Roma, Castel S. Angelo, 7-10 novembre 1995, Rome, 63-72.

Bradshaw P.F. 2014: "What Do We Really Know about the Earliest Roman Liturgy?" Studia Patristica 71, 21-52.

Bradshaw P.F., Johnson M.E. 2012: The Eucharistic Liturgies: Their Evolution and Interpretation, Liturgical Press.

Brandenburg H. 2004: Die frühchristlichen Kirchen Roms vom 4. bis zum 7. Jahrhundert. Der Beginn der abendländischen Baukunst, Milan.

Brandt O. 2014: "The Archaeology of Roman Ecclesial Architecture and the Study of Early Christian Liturgy", Studia Patristica 71, 7-19.
Brandt O. 2016: "L'improbabile legame delle colonne di bronzo al Laterano con il fastigium costantiniano", RACr 92, 117-136.

Branham J.R. 2002: "Bloody Women and Bloody Spaces. Menses and the Eucharist in Late Antiquity and the Early Middle Ages", Harvard Divinity Bulletin 34/4, 15-22.

Brown P. 2012: Through the Eye of a Needle: Wealth, the Fall of Rome, and the Making of Christianity in the West, 350-550 AD, Princeton.

Cabié R. (ed.) 1973: La lettre du pape Innocent $I^{e r}$ a Décentius de Gubbio (19 mars 416). Texte critique, traduction et commentaire, Louvain.

Callam D. 1984: "The Frequency of Mass in the Latin Church ca. 400”, ThS 45 (1984), 613-650.

Caseau B. 2007: "Objects in Churches: the Testimony of Inventories", in L. Lavan, E. Swift, T. Putzeys (eds.), Objects in Context, Objects in Use. Material Spatiality in Late Antiquity, Leiden, 551-579.

Caseau B. 2012: "Constantin et l'encens. Constantin at-il procedé à une révolution liturgique?", in G. Bonamente, N. Lenski, R. Lizzi Testa (eds.), Costantino prima e dopo Costantino, Bari, 535-548.

Cassidy-Welch M. 2010: "Space and Place in Medieval Contexts", Parergon 27/2, 1-12.

Cecchelli M. 1995: "La Basilica di S. Marco a Piazza Venezia (Roma). Nuove scoperte e indagini”, in $A k$ ten des XII. Internationalen Kongresses für christliche Archäologie, Bonn 22.-28. September 1991, vol. 2, Münster, 640-644.

Chavasse A. 1982: 'L'organisation stationnale du Carême romain, avant le $\mathrm{VIII}^{\mathrm{e}}$ siècle. Une organisation 'pastorale"', $R S R$ 56/1, 17-32.

Chavasse A. (tr.) 1997: Textes liturgiques de l'Église de Rome. Le cycle liturgique romain annuel selon le sacramentaire di Vaticanus Reginensis 316, Paris.

Clark E.A. 1990: "Patrons not Priests: Gender and Power in Late Ancient Christianity", Gender \& History 2/3, 253-273.

Clark E.A. 1994: "Ideology, History, and the Construction of 'Woman' in Late Ancient Christianity", JEChrSt 2/2, 155-184.

Coccia S., Fabiani A.G., Prezioso F., Scoppola F. 2000: "Santa Maria in Trastevere: nuovi elementi sulla basilica paleocristiana e altomedievale", MededRom 59, 161-174.

Coccia S., Guidobaldi F., Scoppola F. 2012: "Titulus Iulii (Santa Maria in Trastevere): nuove osservazioni 
sulle fasi più antiche", in $\mathrm{H}$. Brandenburg, F. Guidobaldi (eds.), Scavi e scoperte recenti nelle chiese di Roma. Atti della giornata tematica dei Seminari di Archeologia Cristiana (Roma - 13 marzo 2008), Vatican City, 33-61.

Coebergh C. 1961: "Le Sacramentaire Gélasien ancien: une compilation de clercs romanisants du $\mathrm{VII}^{\mathrm{e}}$ siècle", Archiv für Liturgiewissenschaft 7, 45-88.

Colgrave B., Mynors R.A.B. (eds.) 1969: Bede's Ecclesiastical History of the English People, Oxford.

Cosentino A. 2002: "Il battesimo a Roma: Edifici e liturgia", in F. Guidobaldi, A. Guiglia Guidobaldi (eds.), Ecclesiae Urbis. Atti del Congresso Internazionale di Studi sulle Chiese di Roma (IV-X secolo). Roma, 4-10 settembre 2000, Vatican City, vol. 1, 109-142.

Crossley P. 2010: "Ductus and memoria: Chartres Cathedral and the Workings of Rhetoric", in M. Carruthers (ed.), Rhetoric Beyond Words. Delight and Persuasion in the Art of the Middle Ages, Cambridge, 214-249.

Davis R. (tr.) 1989: The Book of the Pontiffs (Liber Pontificalis). The Ancient Biographies of the First Ninety Roman Bishops to AD 715, Liverpool.

De Benedictis E. 1981: "The Senatorium and Matroneum in the Early Roman Church", $R A C r$ 57, 6985.

De Blaauw S. 1994: Cultus et decor. Liturgia e architettura nella Roma tardoantica e medievale, 2 vols., Vatican City.

De Blaauw S. 1996: "Das Fastigium der Lateranbasilika: Schöpferische Innovation, Unikat oder Paradigma?" in B. Brenk (ed.), Innovation in der Spätantike (Kolloquium Basel 6. und 7. Mai 1994), Wiesbaden, 53-65.

De Blaauw S. 2000: "Premessa", MededRom 59, 1-2.

De Blaauw S. 2001: "L'altare nelle chiese di Roma come centro di culto e della committenza papale", in Roma nell'alto medioevo, Settimane di Studio del Centro Italiano di Studi sull'alto Medioevo, 48, Spoleto, 969-989.

De Blaauw S. 2010: "Le origini e gli inizi dell'architettura cristiana", in S. De Blaauw (ed.), Storia dell'architettura italiana. Da Costantino a Carlo Magno, Milan, 22-53.

De Spirito G. 1993: "Basilia Iulii iuxta Forum Traiani”, in LTUR 1, 180-181.

De Spirito G. 1999: "Transtiberim (età tardoantica)", in LTUR 5, 83-85.

Dey H.W. 2011: The Aurelian Wall and the Refashioning of Imperial Rome, AD 271-855, Cambridge.

Duchesne L. (ed.) 1886-92: Le Liber pontificalis. Texte, introduction et commentaire, 2 vols., Paris.
Duval N. 2005: “L'autel paléochrétien: les progrès depuis le livre de Braun (1924) et les questions à résoudre", Hortus artium medievalium 11, 7-18.

Dyer J. 1993: "The Schola Cantorum and its Roman Milieu in the Early Middle Ages", in P. Cahn and A.K. Heimer (eds.), De musica et cantu. Studien zur Geschichte der Kirchenmusik und der Oper (Helmut Hucke zum 60. Geburtstag), Hildesheim, 19-40.

Dyer J. 2001: "Schola Cantorum", in Grove Music Online, Retrieved 2 Sep. 2019, from https://wwwoxfordmusiconline-com.ezproxy.uio.no/grovemusic/view/10.1093/gmo/9781561592630.001.0001/omo9781561592630-e-0000052368. (accessed 13-III2018).

Dyer J. 2008: "Boy Singers of the Roman Schola Cantorum", in S. Boynton, E. Rice (eds.), Young Choristers, 650-1700, Boydell and Brewer, 19-36.

Einaudi K. B.-S. 2000: "L'arredo liturgico medievale in Santa Maria in Trastevere", MededRom 59, 175194.

Ellard G. 1948: "How Fifth-century Rome administered Sacraments: St. Innocent I advises an Umbrian Bishop", ThS 9/1, 3-19.

Elsner J. 2006: "From Empirical Evidence to the Big Picture: Some Reflections on Riegl's Concept of Kunstwollen", Critical Inquiry 32, 741-766.

Emerick J.J. 2000: "Focusing on the Celebrant: the Column Display inside Santa Prassede", MededRom 59, 129-159.

Gauckler P. 1906: "Mosaïques tombales d'une chapelle des martyrs à Thabraca", MonPiot 13/2, 175228.

Geertman H. 1987: "Le capacità de metretae, amae, e scyphi nel Liber pontificalis" (1987), rept. in S. De Blaauw (ed.), Hic fecit basilicam. Studi sul Liber pontificalis e gli edifici ecclesiastici di Roma da Silvestro a Silverio, Leuven etc., 2004, 45-51.

Geertman H. 2001-2002: "Il fastigium lateranense e l'arredo presbiteriale. Una lunga storia", MededRom 60-61, 29-43.

Grubbs J.E. 1993: "Constantine and Imperial Legislation on the Family", in J. Harries, I. Wood (eds.), The Theodosian Code, Ithaca NY, 120-142.

Gryson R. 1976: The Ministry of Women in the Early Church, tr. J. Laporte, M. L. Hall, Collegeville MN.

Guenther O. (ed.) 1895: "Quae gesta sunt inter Liberium et Felicem Episcopos", in Epistulae imperatorum pontificum aliorum inde $a b a$. CCCLXVII usque ad a. DLIII datae, Avellana quae dicitur collectio, vol. 1, Prague, 1-4.

Guidobaldi F. 2001-2002: "La fondazione delle basiliche titolari di Roma nel IV e V secolo. Assenze e presenze nel Liber Pontificalis", MededRom 60-61, 5-12. 
Guidobaldi F. 1989: "L'inserimento delle chiese titolari di Roma nel tessuto urbano preesistente: Osservazioni e implicazioni", in Quaeritur inventus colitur. Miscellanea in onore di padre Umberto Maria Fasola, B., Vatican City, 381-396.

Guidobaldi F. 2000: "L'organizzazione dei tituli nello spazio urbano", in L. Pani Ermini (ed.), Christiana loca. Lo spazio cristiano nella Roma del primo millennio, 2 vols., Rome, 1, 123-129.

Guidobaldi F. 2001: "Strutture liturgiche negli edifici cristiani di Roma dal IV al VII secolo", in M. Cecchelli (ed.), Materiali e tecniche dell'edilizia paleocristiana a Roma, Rome, 171-190.

Hansen M.F. 2003: The Eloquence of Appropriation. Prolegomena to an Understanding of Spolia in Early Christian Rome, Rome.

Hillner J. 2007: "Families, Patronage and the Titular Churches of Rome, c, 300-c. 600", in K. Cooper, J. Hillner (eds.), Religion, Dynasty, and Patronage in Early Christian Rome, 300-900, Cambridge, 225261.

Humphries M. 2014: "Liturgy and Laity in LateAntique Rome: Problems, Sources, and Social Dynamics", Studia Patristica 71, 171-186.

Hunter D.G. 2009: "The Significance of Ambrosiaster", JEChrSt 17/1, 1-26.

Jensen R.M. 2014: "Saints' Relics and the Consecration of Church Buildings in Rome", Studia Patristica 71, 153-169.

Jensen R.M. 2015: "Recovering Ancient Ecclesiology: The Place of the Altar and the Orientation of Prayer in the Early Latin Church", Worship 89, 99-124.

John Paul II 2003: Ecclesia de Eucharistia, from https://w2.vatican.va/content/john-paul-ii/en/encyclicals/documents/hf_jp-ii_enc_20030417_eccl-deeuch.html (accessed 07-III-2018).

Kinney D. 1975: "Excavations in S. Maria in Trastevere, 1865-1869: A Drawing by Vespignani”, RömQSchr 70, 42-53, Taf. 5-7.

Kinney D. 2010: "Edilizia di culto cristiano a Roma e in Italia centrale dalla metà del IV al VII secolo", in S. De Blaauw (ed.), Storia dell'architettura italiana. Da Costantino a Carlo Magno, Milan, 54-97.

Kirsch J.P. 1926: Die Stationskirchen des Missale Romanum, Freiburg im Breisgau.

Krautheimer R., Pentiricci M. 2009: "La basilica di San Lorenzo nei secoli IV-X”, in C.L. Frommel, M. Pentiricci (eds.), L'antica basilica di San Lorenzo in Damaso. Indagini archeologiche nel Palazzo della Cancelleria (1988-1993), Rome, 266-276.

Llewellyn P. 1970: Rome in the Dark Ages, New York. Louth A. 1996: "Unity and Diversity in the Church of the Fourth Century", in R.N. Swanson (ed.), Unity and Diversity in the Church. Papers read at the 1994
Summer Meeting and the 1995 Winter Meeting of the Ecclesiastical History Society, Oxford, 1-17.

Lunn-Rockliffe S. 2007: Ambrosiaster's Political Theology, Oxford.

MacMullen R. 2009: The Second Church. Popular Christianity A.D. 200-400, Leiden.

Maischberger M. 1999: "Transtiberim", in LTUR 5, 77-83.

Marazzi F. 2001: “Aristocrazia e società (secoli VIXI)", in A. Vauchez (ed.), Roma medievale, Bari, 4169.

Marcovich M. (ed.) 1986: Hippolytus. Refutatio omnium haeresium, Berlin-New York.

Mathews T.F. 1962: “An Early Roman Chancel Arrangement and its Liturgical Functions", $R A C r$ 38, 73 95.

Mathews T.F. 1993: The Clash of Gods. A Reinterpretation of Early Christian Art, Princeton.

Mohlberg L.C. (ed.) 1960: Liber Sacramentorum Romanae Aecclesiae ordinis anni circuli (Cod. Vat. Reg. lat. 316/Paris Bibl. Nat. 7193, 41/56) (Sacramentarium Gelasianum), Rome.

Mommsen T. (ed.) 1892: "Chronographus anni CCCLIIII", in Monumenta Germaniae Historica, Auctores antiquissimi, vol. 9, Chronica minora saec. IV. V. VI. VII. Berlin, 39-148.

Mommsen T. (ed.) 1894: "Acta synhodi a. CCCCXCVIIII", in Monumenta Germaniae Historica, Auctores antiquissimi, vol. 12, Cassiodori Senatoris variae (new ed. 1961), 399-415.

Muschiol G. 2004: "Men, women and liturgical practice in the early medieval west", in L. Brubaker, J.M. Smith (eds.), Gender in the Early Medieval World. East and West, 300-900, Cambridge, 198-216.

Palazzo É 2008: L'espace rituel et le sacré dans le christianisme. La liturgie de l'autel portatif dans l'Antiquité et au Moyen Âge, Turnhout.

Purcell N. 1999: "The populace of Rome in late antiquity: problems of classification and historical description", in W.V. Harris (ed.), The Transformations of Vrbs Roma in Late Antiquity, Portsmouth RI, 135-161.

Repsher B. 1998: The Rite of Church Dedication in the Early Medieval Era, Lewiston NY.

Rolfe J.C. (tr.) 1971-1972: Ammianus Marcellinus, 3 vols., Cambridge MA.

Romano J.F. 2014: Liturgy and Society in Early Medieval Rome, Farnham UK.

Salzman M.R. 2002: The Making of a Christian Aristocracy. Social and Religious Change in the Western Roman Empire, Cambridge MA.

Saxer V. 2000: "Recinzioni liturgiche secondo le fonti letterarie", MededRom 59, 71-79. 
Sessa K. 2012: The Formation of Papal Authority in Late Antique Italy. Roman Bishops and the Domestic Sphere, Cambridge.

Sotinel C. 1997: “Locus orationis ou domus Dei? Le témoignage du Zénon de Vérone sur l'évolution des églises (tractatus II.6)", Studia Patristica 29, 141147.

Spera L. 2013: "Il vescovo di Roma e la città: regioni ecclesiastiche, tituli, e cimiteri. Ridefinizione di un problema amministrativo e territoriale", in Atti del XV Congreso Internacional de Arqueologia Cristiana (Toledo, 8-12 septiembre 2008), Vatican City, 163-198.

Taft R. F. 2000a: A History of the Liturgy of St. John Chrysostom, vol. 5, The Precommunion Rites, Rome.

Taft R.F. 2000b: “'Eastern Presuppositions' and Western Liturgical Renewal", Antiphon 5/1, 10-22.

Thunø E. 2011: "Inscription and divine presence: golden letters in the early medieval apse mosaic", Word \& Image 27/3, 279-291.

Thun $\varnothing$ E. 2015: The Apse Mosaic in Early Medieval Rome: Time, Network, and Repetition, Cambridge.

Verrando G.N. 2004a: "Cal(1)isti Coemeterium (Via Aurelia)", in LTUR Suburbium 2, 44-50.
Verrando G.N. 2004b: "Callistum (ad), Basilica", in LTUR Suburbium 2, 50-54.

Vogel C. 1986: Medieval Liturgy: An Introduction to the Sources, rev. and tr. W.G. Storey, N.K. Rasmussen, O.P., The Pastoral Press.

Ward-Perkins J.B., Goodchild R.G. 1953: "The Christian Antiquities of Tripolitania", Archaeologia 95, 184

White L.M. 1990: "Penance", in E. Ferguson (ed.), Encyclopedia of Early Christianity, New YorkLondon.

Wickham C. 2015: Medieval Rome. Stability and Crisis of a City, 900-1150, Oxford.

Wijngaards J. 2001: The Ordination of Women in the Catholic Church. Unmasking a Cuckoo's Egg Tradition, London.

Wohl B.L. 2001: "Constantine's Use of Spolia”, in J. Fleischer, N. Hannestad, J. Lund, M. Nielsen (eds.), Late Antiquity - Art in Context, Copenhagen, 85-115.

Wood C.T. 1981: "The Doctor's Dilemma: Sin, Salvation, and the Menstrual Cycle in Medieval Thought", Speculum 56/4, 710-727. 


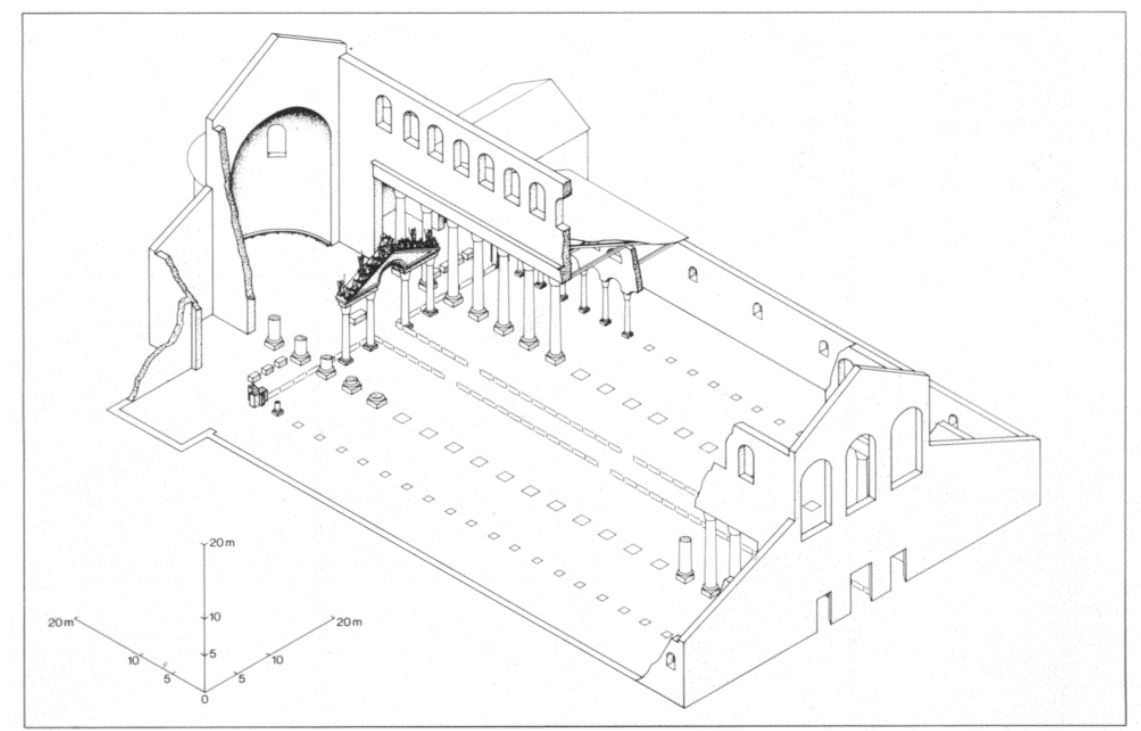

FIG. 1 - Rome, San Giovanni in Laterano, reconstruction of the Constantinian basilica. Source: De Blaauw 1994, vol. 2, Fig. 2.

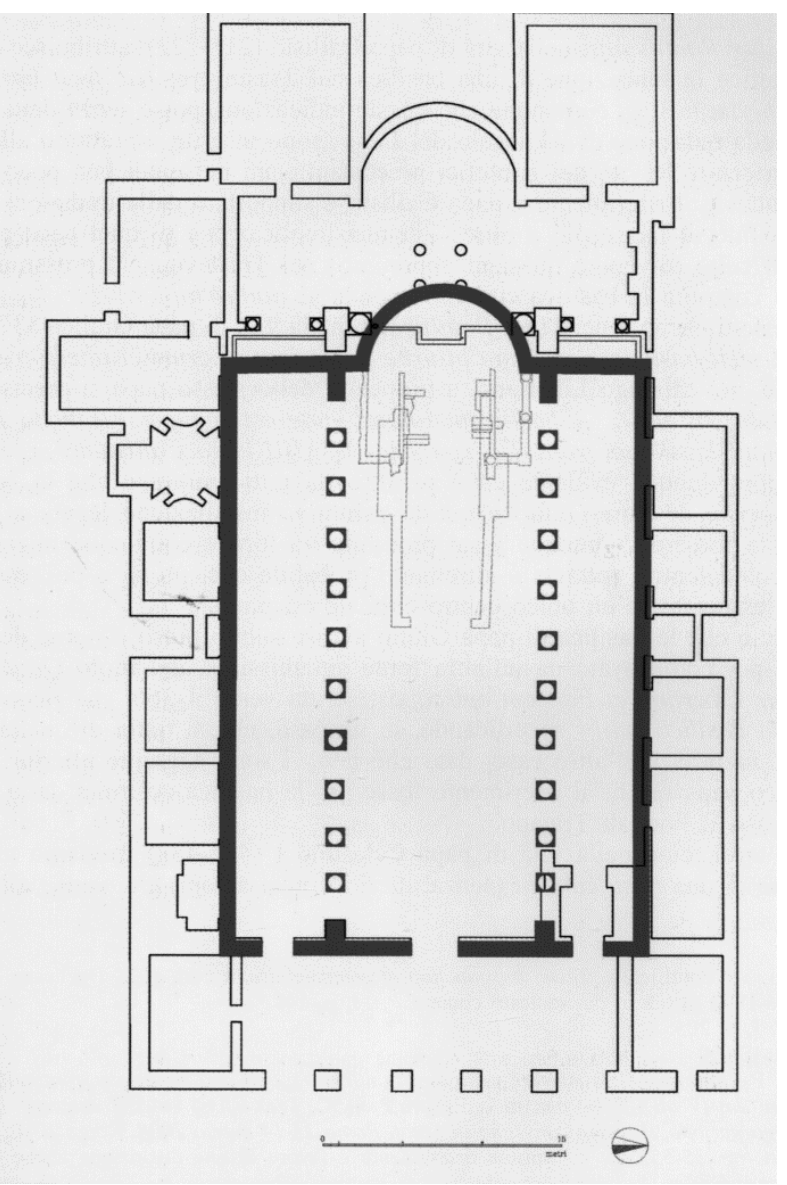

FIG. 2 - Rome, Santa Maria in Trastevere, ground plan with outline of the Basilica Julii. Source: Coccia et al. 2012, Fig. 19. 

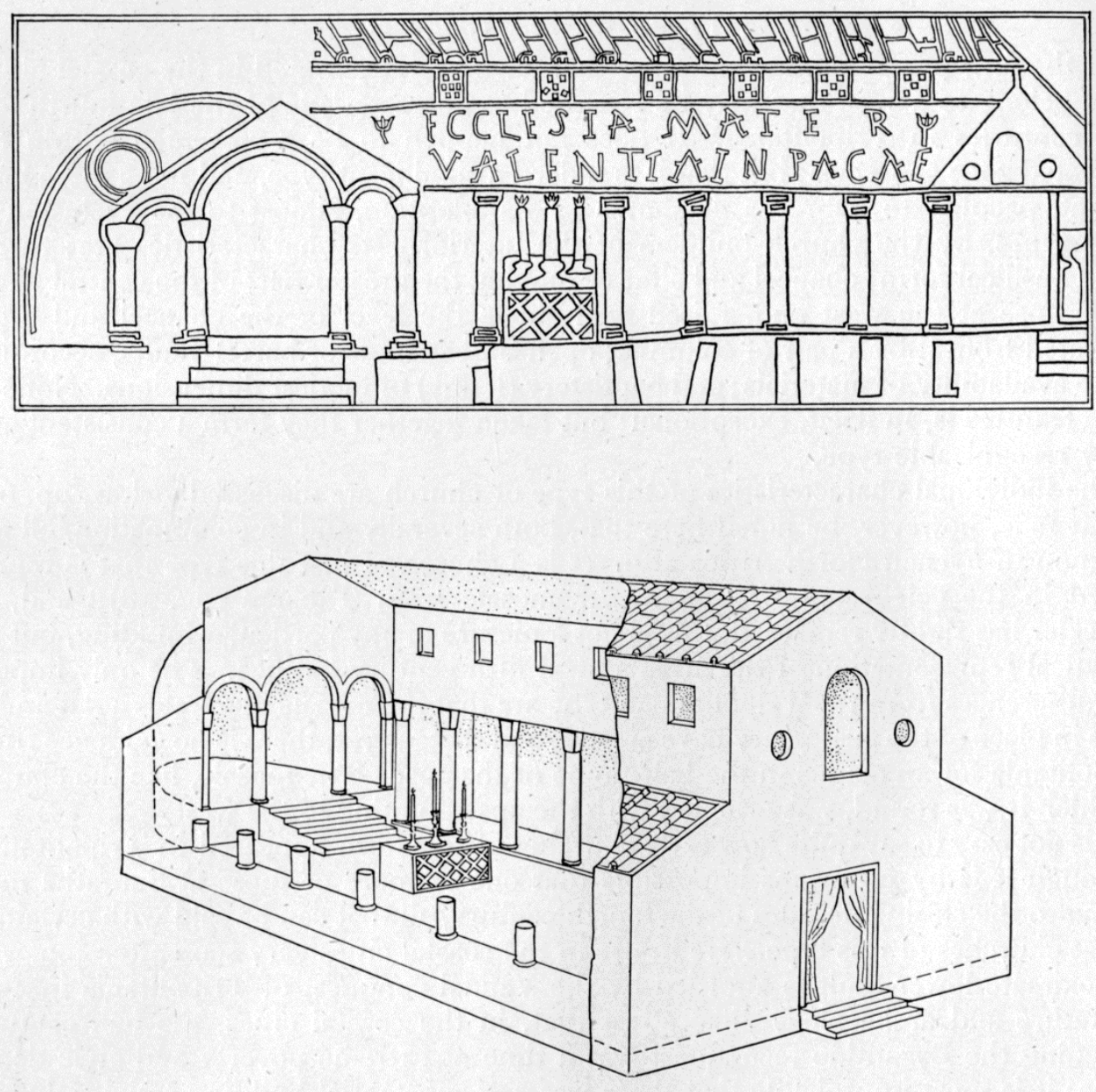

FIG. 3 - Tunis, Bardo National Museum, mosaic of Ecclesia Mater, graphic rendering and reconstruction of the depicted basilica. Source: Ward-Perkins and Goodchild 1953, 58 Fig. 28. 


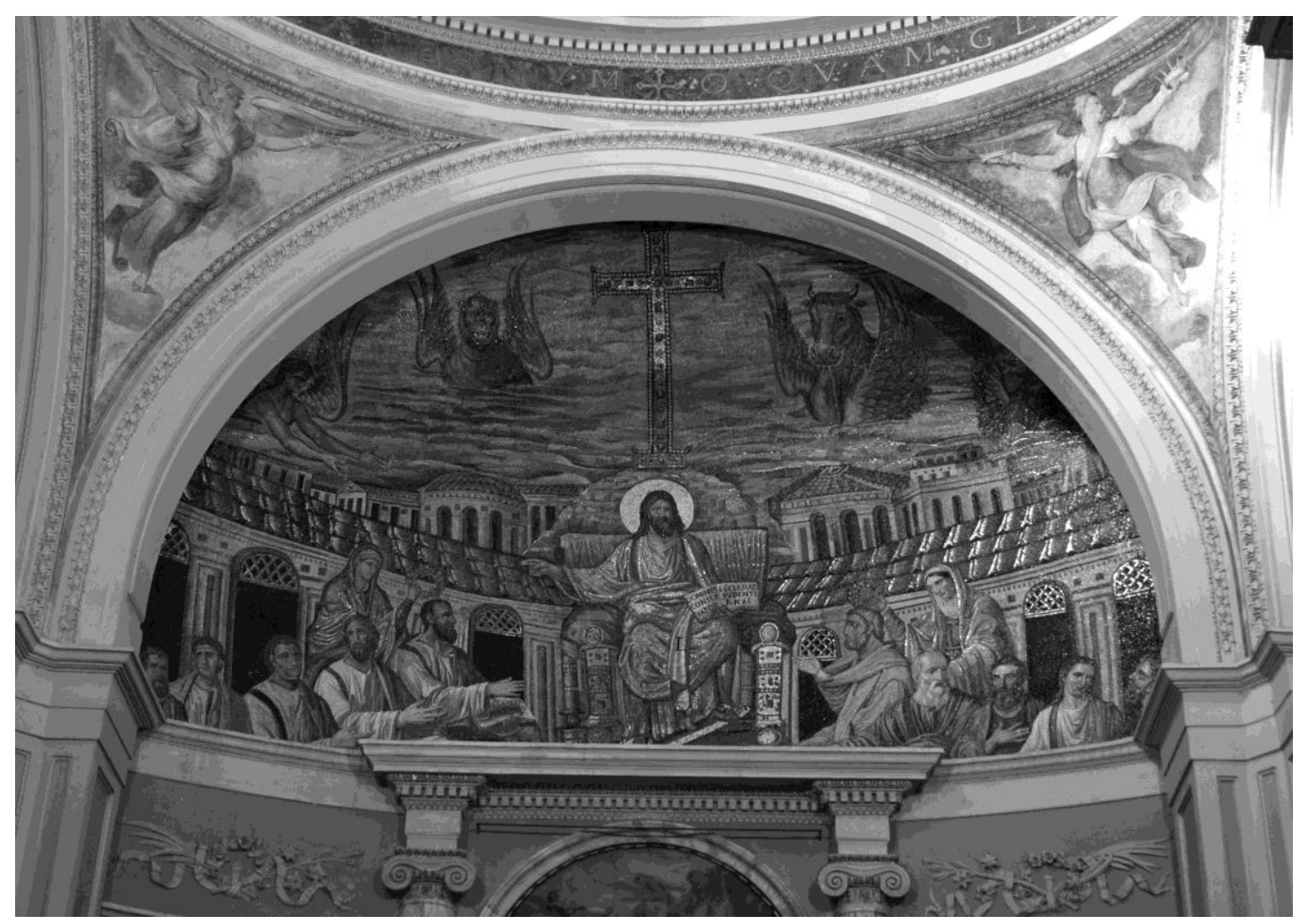

FIG. 4 - Rome, Santa Pudenziana, apse mosaic, 410-417. Photo: author.

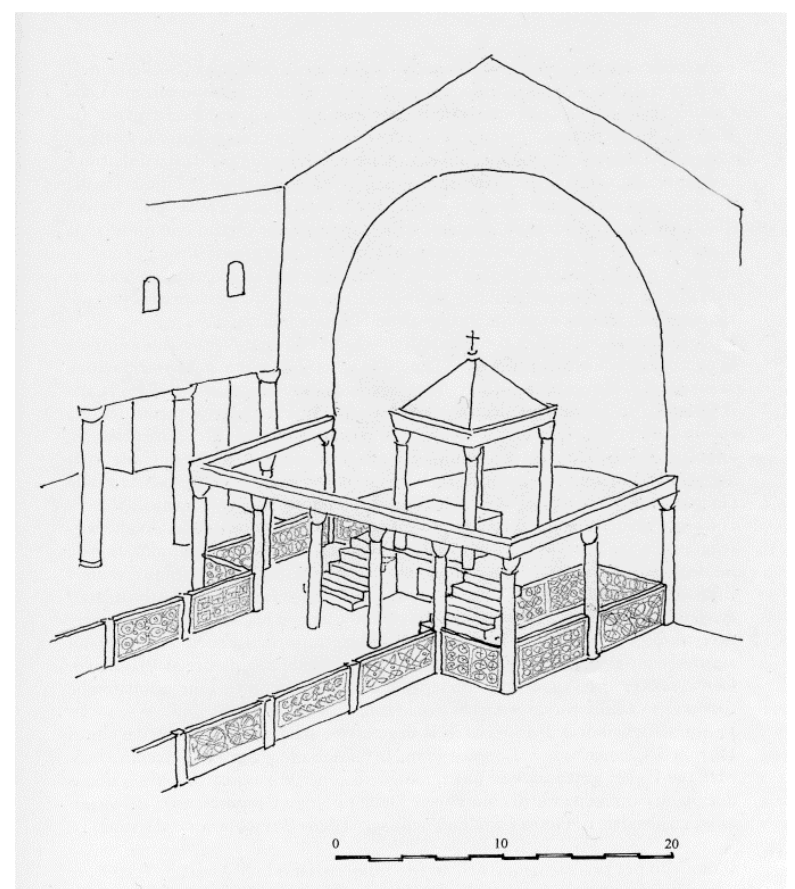

FIG. 5 - Rome, Santa Maria in Trastevere, remodeling of Pope Gregory IV, reconstruction by Karin Einaudi. Source: Einaudi 2000, 185 Fig. 4. 